\title{
PS-055-3 多発性肺腺癌の切除例の検討
}

1 独立行政法人国立病院機椪刀根山病院呼吸器外科, ${ }^{2}$ 独立行政法人国立病院 機構刀根山病院病理科

楠 貴志 ${ }^{1}$, 武田 伸一 ${ }^{1}$, 門田 嘉久 ${ }^{1}$, 船越 康信 ${ }^{1}$, 野屋 崇 ${ }^{1}$, 川村 知裕 ${ }^{1}$, 前田 $\vec{\tau}^{1}$, 上田 佳世 $^{2}$

【背景と目的】近年，胸部 CT 診断の進歩により，GGO病変を伴う多発性肺 腺癌が報告されるようになった。転移・再発病変とは異なりその予後が良好 なことが報告されている. 今回, 自験例での多発性肺腺癌の切除例を臨床病 理学的に検討した．【結果】1997 2006年に当科では885件の肺痹手術を行っ

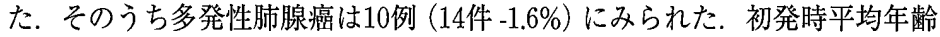
は65.4歳 (42 78歳)。男性1例，女性9例。同時性8例 (80\%), うち2例に遠隔

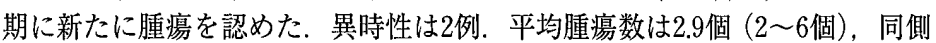

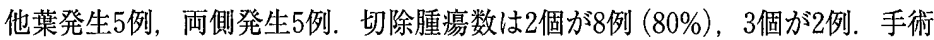
は，同時性肺癌のうち 3 例が両側例であり，二期的に部切・葉切を行ったも の1例，片側の部切の久行ったもの2例．他は片側例で二葉切＋区切1例，二 葉切1例（他側に腫場が新発生し経過観察中），葉切+部切2例（うち1例で同 側に腫韵が新発生し完遂全摘)，葉切1例。異時性肺癌は両側1例，同側1例で， 初回手術はどちらも葉切であったが，再手術は両側例では部切，同側例では 区切を行った，すべての手術は安全に施行され，術後合併症は認めなかった。 切除腫晹の組織型は細気管支肺胞上皮 (以下, BAC) 型の及が6例 (60\%), 乳 頭型のみ 1 例， $\mathrm{BAC}$ と $\mathrm{BAC}$ 以外の組織型の合併例が2例，他1例で， $\mathrm{BAC}$ 型を含むものは8例 $(80 \%$ ）に認めた。いずれもリンパ節転移を認めず，病理 病期は IA 期が6例，IB 期が4例であった．初回手術時からの中間観察期間は 38ヶ月で全員生存中であり，うち3例は5年以上生存している.

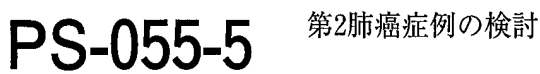

\section{独立行政法人国立病院機構九州医療センター呼吸器部門外科}

松澤 宏典, 山口 正史, 末満 隆一, 岡崎 寛士, 日高 仁, 田中弘二, 竹尾 貞德

【目的】肺癌術後の経過観察と第2癌の治療法には現在まで明確な指標がない． 原発性肺癌術後，異時性に発生した第2肺癌の再切除について検討した。【方 法]1984年〜2006年まで，当科で手術を施行した895例中，異時性に発生した 第2肺癌を切除された12例（1.3\%）を対象として検討した，異時性の診断は Martini らによる診断基準を参考にした．【結果】男性9例，女性3例，第2癌 手術時の平均年齢は67.3歳 (47 79歳). 第2癌までの手術間隔は平均 61.9 ケ月 (6.5 206.8 月 月), 予後は平均97.8（13２35.1ケ月）. 初回の術式は, 葉切除 10 例，2葉切除1例，区域切除1例. 第2癌は葉切除2例，区域切除3例，部分切 除7例. 初回の病理病期は IA 期4例，IB 4例，IIA 期1例，IIIB 期1例，不明 2 例，第2癌は IA 期8例，IB 期2例，IIIA 期 2 例。初回の組織型は腺癌5例，扁 平上皮癌3例，不明4例，第2癌は腺癌8例，扁平上皮癌3例，多型癌1例の結果 を得た【結論】第2癌の早期発見には，定期的な経過観察が必要であり，長 期経過後に第2癌の発生を念頭に置く必要がある。第2癌を早期発見できれば 根治度の可能性が高まり生存率の向上が望める。肺機能が許す限り根治術に 準じた解剖学的手術を検討すべきである。

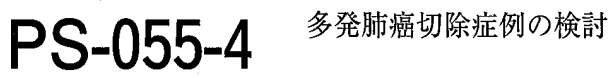

\section{名古屋大学医学部呼吸器外科}

内山 美佳, 川口 晃司, 岡阪 敏樹, 伊藤 志門, 佐藤 尚他, 谷口 哲郎, 宇佐美 範恭, 横井 香平

【目的】当院における多発肺癌の切除成績，問題点について検討した：【対象】 1996年1月から2006年10月の間に切除され病理学的に上皮内病変の存在や形 態学的な違いおよび Martini\&Melamed の定義により多発癌と考えられた23 例を調查・分析とした。【結果】男性15例，女性8例。平均年齢69.1藏。組織 型は腺癌一腺癌17例; 扁平上皮癌一扁平上皮癌了例，腺癌一扁平上皮癌例， 腺癌一腺扁平上皮癌1例， 3 重癌も3例あった，異時性6例，同時性17例であっ た．異時性多発肺癌では第2癌出現までに平均 $56 \pm 32$ 个経過していた，初 回手術はすべて肺葉切除以上であり2回目以降は2例に肺葉切除，4例に部分 切除を施行. 同時性多発肺癌では, 一期的切除を 9 例, 二期的切除を 8 例に施 行. 部分切除一肺葉切除8例，肺葉切除一肺葉切除5例，肺葉切除の及（同一 肺葉内に多発癌あり）2例，部分切除一区域切除1例，肺全摘1例で重篤な合併 症は1例が肺梗塞で5日目に死亡し，二期的に両側の肺葉切除を施行した1症 例が換気障害を生じ7日間人工呼吸管理を必要とした。全体で10例( $43.5 \%$ に 再発を認めた，扁平上皮癌症例はすべて再発しており，第2癌出現までに6年 以上経過した2症例も術後早期に再発を来たした。，全体ではリンパ節転移を 認めた5症例が全て再発した.【結語】肺内転移か多発癌かの区別は困難なこ とが多く，今回も肺内転移であった症例も含まれていたため再発率が高かっ た可能性が考えられる．多発癌で扁平上皮癌やリンパ節転移を認める症例の 再発率は高く，術式と症例の選択を考慮するべきであると思われた。

PS-055-6

肺癌（再発，第 2 癌）における Completion pneumonectomy の検討

西神戸医療センター呼吸器外科

今村 直人, 青木 秎, 中西 崇雄, 大竹 洋介

【目的】 Completion pneumonectomy (CP) は侵襲が大きく, 重篤な術後合併 症や手術関連死亡が多いとされる。一方で肺癌 (再発，第2癌)においても病 变が遺残肺に限局している場合は， $\mathrm{CP} に よ り$ 長期生存を得られる症例もみ とめる。そこで当院での肺癌（再発，第2癌）に扔ける $\mathrm{CP}$ 症例について検討 を行った.【対象】区域切除以上の肺切除後に施行された $\mathrm{CP}$ を対象とした. 1994年8月から2006年11月までに施行された CP 症例は13例であった。この うち肺癌で肺切除を行い，再発，第2癌をきたして $\mathrm{CP}$ を行った症例は 5 例で あった.【結果】男性 4 例, 女性 1 例. 年龄5 $5 \sim 77$ 歳 (平均 67.8 歳). 再発 4 例, 第2癌1例，初回手術より CP までの期間は19 112ヶ月(平均45.1ヶ月)。手術 時間338 566分 (平均 434 分)。術中出血 $975 \mathrm{~g} \sim 3700 \mathrm{~g}$ (平均 $2591 \mathrm{~g}$ ). 予後性生 存3例（術後4 7年経過，うち担癌生存1例)，死亡 2 例であった. 死亡のうち わけは，突然死1例(術後34日), 癌死1例(術後17ケ月)であった。術後合併症 は気管支断端瘦 2 例，反回神経麻痺1例みとめた。 なお， $\mathrm{CP}$ 全 13 症例では去

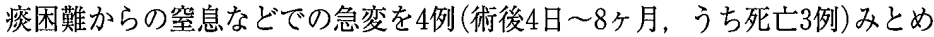
た. 【考察】 CP は長時間の手術で出血量も多く，十分な術中術後管理が必要 であった，合僧症としては気管支断端瘦や去痰困難に特に注意を要すると考 えられた，再発肺癌でも長期生存を得られている症例もあり，症例を慎重に 選択すれば，CP は有効であるが，患者に危険性について十分な説明が必要 であると考えられた。 